\title{
Cold Storage of Two Selections of Soursop (Annona muricata L.) in Nayarit, Mexico
}

\author{
José Orlando Jiménez-Zurita, ${ }^{1}$ Rosendo Balois-Morales, ${ }^{2}$ Irán Alia-Tejacal, ${ }^{3}$ \\ Leticia Mónica Sánchez Herrera, ${ }^{2}$ Edgar Iván Jiménez-Ruiz, ${ }^{2}$ Juan Esteban Bello-Lara, ${ }^{1}$ \\ Juan Diego García-Paredes, ${ }^{4}$ and Porfirio Juárez-López ${ }^{3}$ \\ ${ }^{1}$ Posgrado en Ciencias Biológico Agropecuarias, Universidad Autónoma de Nayarit, Ciudad de la Cultura S/N, Col. Centro, \\ 63000 Tepic, NAY, Mexico \\ ${ }^{2}$ Universidad Autónoma de Nayarit, Ciudad de la Cultura S/N, Col. Centro, 63000 Tepic, NAY, Mexico \\ ${ }^{3}$ Posgrado en Ciencias Agropecuarias y Desarrollo Rural, Universidad Autónoma del Estado de Morelos, Av. Universidad Núm. 1001, \\ Col. Chamilpa, 62209 Cuernavaca, MOR, Mexico \\ ${ }^{4}$ Unidad Académica de Agricultura, Universidad Autónoma de Nayarit, Km. 9 Carretera Tepic-Compostela, Xalisco, NAY, Mexico
}

Correspondence should be addressed to Rosendo Balois-Morales; balois_uanayar@hotmail.com

Received 11 November 2016; Revised 18 January 2017; Accepted 12 February 2017; Published 14 March 2017

Academic Editor: Ignacio García-Estévez

Copyright (C) 2017 José Orlando Jiménez-Zurita et al. This is an open access article distributed under the Creative Commons Attribution License, which permits unrestricted use, distribution, and reproduction in any medium, provided the original work is properly cited.

\begin{abstract}
The maturity of two selections of soursop (G1 and G2) from Nayarit, Mexico, was evaluated under environmental conditions at $22^{\circ} \mathrm{C}$ and refrigeration at $15^{\circ} \mathrm{C}$ stored for 6 and 8 days, respectively. Maximum $\mathrm{CO}_{2}$ and ethylene values were present on the fifth and sixth day. The fruits exposed at $15^{\circ} \mathrm{C}$ had a significantly lower weight loss (5\%) and showed no chilling injury. The firmness of two selections decreased more than $90 \%$. The concentration of TSS increased to 5.3 to $15^{\circ}$ Brix, and the titratable acidity was higher for fruit stored at $22^{\circ} \mathrm{C}$. The highest concentration of phenols was recorded on the fourth day of storage at $22^{\circ} \mathrm{C}$. The enzymatic activity of PPO was increased from physiological ripening to consumption ripening for both treatments. The two selections stored at $22^{\circ} \mathrm{C}$ registered the highest level of PME activity at ripeness. Shelf life was increased by up to 8 days ( 4 days at $15^{\circ} \mathrm{C}$ plus 4 days at $22^{\circ} \mathrm{C}$ ) without causing chilling injury or alterations in the ripening process of the fruits. No significant differences were observed between the two selections evaluated; postharvest handling was considered to be similar; however, it would be advisable to evaluate other technologies combined with refrigeration.
\end{abstract}

\section{Introduction}

The soursop (Annona muricata L.) is a fruit tree native to tropical America [1]. Morton [2] and Paull and Duarte [3] suggest that it originated in the Caribbean and the northern region of South America. It is currently found from South Eastern China to Australia, as well as tropical areas of Africa [2]. Due to its organoleptic properties, the fruit of the soursop is considered suitable for both processed and fresh local consumption [3]. It is farmed extensively in Mexico, from Sinaloa to Chiapas in the Pacific region and from Veracruz to Yucatán in the Gulf region, and in other countries such as Brazil and Venezuela [3]. In Mexico in 2013, soursop was farmed over approximately 2724 ha, with an average yield of $8.5 \mathrm{tha}^{-1}$ and a total production value of close to 105 million pesos [4]. Approximately $73 \%$ of the surface area dedicated to the farming of the soursop in the country is found in the state of Nayarit [4]. Soursop is exported throughout the year, and an increase in the levels of average fresh consumption has been observed in the market [5].

The taste of the soursop fruit results from the combination of sugars and acids (0.65-0.85\%), with its pulp containing $1 \%$ protein, $18 \%$ carbohydrates, $1 \%$ fiber, vitamins $\mathrm{B} 1, \mathrm{~B} 2$, and $\mathrm{C}$, and phenols, flavonols, and acetogenins $[5,6]$. The compounds mentioned at the end of the above list are associated with the prevention of conditions related to free 
TABLE 1: Average values for morphological and chemical variables for two selections of soursop in Tepic, Nayarit [16].

\begin{tabular}{cccccccccccc}
\hline & SN & SW & PW & PW $^{1}$ & L $^{*}$ & C $^{*}$ & $h$ & $M$ & pH & TSS & TA \\
\hline G1 & 104.55 & 73.07 & 246.26 & 728.43 & 40.12 & 16.13 & 159.41 & 1361.71 & 3.79 & 10.97 & 0.6 \\
G2 & 187.60 & 123.28 & 264.13 & 1027.08 & 37.70 & 16.31 & 158.40 & 1718.48 & 3.58 & 10.44 & 0.8 \\
\hline
\end{tabular}

$\mathrm{SN}=$ seed number; $\mathrm{SW}=$ seed weight $(\mathrm{g}) ; \mathrm{PW}=$ peel weight $(\mathrm{g}) ; \mathrm{PW}^{1}=$ pulp weight $(\mathrm{g}) ; \mathrm{L}^{*}=$ luminosity $\left(0\right.$ : white, 100 : black); $\mathrm{C}^{*}=$ chromaticity (grey); $h=$ hue angle (0: red; 180: green); $M=$ mass (g); TSS = total soluble solids $\left({ }^{\circ} \mathrm{Brix}\right) ; \mathrm{TA}=$ titratable acidity $(\%)$.

radicals [7]. However, it is important to mention that research indicates that frecuent consumption of the fruit or other parts of the soursop tree (leafs, bark, and seeds) can have a harmful effect on human health $[8,9]$.

The soursop fruits, when harvested and ripened at room temperature, may reach consumer maturity in 2,3 , or up to 7 days depending on the maturation stage in which they were harvested $[1,10]$. A service life of between 4 and 8 days for soursop fruit ripened at $25^{\circ} \mathrm{C}$ has been reported in Nayarit $[11,12]$, denoting a highly perishable product. TovarGómez et al. [13] describe a postharvest loss of $60 \%$ due to the perishable nature and the physical fragility of this fruit, causing the exportation of the soursop to be undertaken on the day of harvest via airplane at a temperature of $13^{\circ} \mathrm{C}$, which has proven very costly.

Refrigeration is the most important postharvest technology for maintaining quality and reducing the speed of the deterioration of harvested horticultural products, as it is widely accepted that the speed of postharvest deterioration is closely related to the speed at which the product respires, which is itself dependent on temperature [14]. Little information is available on the refrigeration temperatures required for increasing the shelf life of the soursop. Thus, working with fruits from La Peñita de Jaltemba, Nayarit, Mexico, CastilloÁnimas et al. [15] recommend the storage of fruits of a light green color with a changing-firm texture in between 12 and $18^{\circ} \mathrm{C}$. Lima and Alves [5] indicate that, in Brazil, fruits stored at $15^{\circ} \mathrm{C}$ require 9 days to ripen.

Soursop fruit harvested in El Tonino, Nayarit, and stored at $16^{\circ} \mathrm{C}$ with the application of 1-methylcyclopropene (1MCP) require between 8 and 9 days to ripen [11]. The studies undertaken in Mexico do not indicate the variety of plant or the type of vegetable material used in the evaluation, which is attributed to the fact that, currently, there are no varieties of the soursop, for which reason, all studies were undertaken with fruit originating from seed-propagated trees.

Recently, Jiménez-Zurita et al. [16] carried out a morphological and chemical characterization of fruits originating from ungrafted trees in Tepic, Nayarit. The results helped to separate four groups of trees, where the principal variables assisting their formation were the mass, dimensions, and color of the epidermis. The formation of groups indicates a variability in the morphological and chemical characteristics of the fruit, for which it is necessary to study the postharvest physiology and biochemistry of this fruit in order to devise adequate postharvest handling. Differences are known among cultivars within the same species in terms of chemical characteristics, such as sugar content [14]. Studies on the refrigeration of the soursop have evaluated basic postharvest physiological and biochemical characteristics, such as respiration, the production of ethylene, titratable acidity, total soluble solids, and firmness [5]. However, the metabolism of phenols and the enzymatic activity of both polyphenol oxidase and pectin methylesterase has been explored little. The large part of the biochemical changes produced in the fruit are caused by enzymes, which are responsible for ripening it, as well as the formation of its sensory characteristics and senescence. The enzyme polyphenol oxidase (EC.1.14.18.1; PPO) is important in the oxidative degradation of phenolic compounds in terms of quality, in that it leads to darkening through the catalyzation of two different reactions in the presence of molecular oxygen: (a) the hydroxylation of monophenols to ortho-diphenols and (b) the oxidation of ortho-diphenols to ortho-quinones $[17,18]$.

Loss of firmness is observed to be influenced by the enzyme pectin methylesterase (EC. 3.1.1.11; PME), which is related to the degradation of the pectin substances of the middle lamella of the cellular component of the cellular wall [19].

The objective of this research was to characterize the physicochemical and biochemical changes occurring in two selections of soursop fruit during postharvest cold storage to obtain information that may help to increase its shelf life and facilitate its potential commercialization as a fresh product.

\section{Materials and Methods}

Fruit was harvested in two selections (G1 and G2) in July 2015 from ungrafted trees in a 15-year-old orchard in Tepic, Nayarit, Mexico $\left(21^{\circ} 32^{\prime} 2.77^{\prime \prime} \mathrm{N}, 104^{\circ} 58^{\prime} 39.73^{\prime \prime} \mathrm{O}, 893 \mathrm{msnm}\right.$ ) [16]. The fruit in selection G1 had low acidity, a higher $\mathrm{pH}$, and intermediate total soluble solid values (Table 1). The fruit in selection G2 demonstrated higher seed numbers, total mass, peel, and pulp mass, in addition to a higher titratable acidity value (Table 1).

A harvest index reported by the producer was used, which counts 160 days after anthesis, when the fruit acquires a light green or yellowish color [20]. The fruit selected did not present physical or pathogenic damage. The harvest was carried out between seven and eight a.m., with the fruit then placed in plastic boxes and taken by land transport to the Agricultural Production Laboratory of the Faculty of Agricultural and Livestock Sciences at the Autonomous University of the State of Morelos. Two selections of soursop and two storage temperatures $\left(15\right.$ and $\left.22^{\circ} \mathrm{C}\right)$ were evaluated. A total of thirty-six soursop fruits per selection were acclimatized for $1 \mathrm{~h}$ at room temperature $\left(22^{\circ} \mathrm{C}\right)$ and then placed in controlled temperature chambers (OLG HOT TEMP No. OLG-800D). 
Four treatments were designed: (1) selections G1 and G2 stored at $22^{\circ} \mathrm{C}$, with $85 \% \mathrm{RH}$ for 8 days; (2) selections $\mathrm{Gl}$ and G2 stored at $15^{\circ} \mathrm{C}$ for 4 days and at $22^{\circ} \mathrm{C}$ for 4 days, with $85 \%$ $\mathrm{RH}$. Temperature and relative humidity were monitored with a Data Logger (HOBO U12).

Daily nondestructive analysis was conducted on a group of six fruits per treatment for the loss of mass, respiration and ethylene production variables. Destructive analysis was used to determine firmness, total soluble solids, titratable acidity, phenolic compounds, the enzymatic activity of polyphenol oxidase, and pectin methylesterase at the beginning of the experiment, on the 4 th and 6th days, when the fruit was being kept at $22^{\circ} \mathrm{C}$ and when the fruit was removed from storage at days 0 and 4 . The experimental design was randomized and the experimental unit was one fruit with six duplicates on different fruits.

2.1. Respiration and Ethylene. The respiration rate and ethylene production were quantified using a static system [21] that is comprised of placing an intact fruit with a known mass in containers with a known volume $(4 \mathrm{~L})$ and hermetically sealing for $1 \mathrm{~h}$. Subsequently, a $1 \mathrm{~mL}$ sample of air was taken from the headspace and injected into an Agilent Technologies 7890A GC Wilmington, USA gas chromatograph, with an open type column and a porous silica cap seal simultaneously connected to a thermal conductivity detector and a flame ionization detector at a temperature of $170^{\circ} \mathrm{C}$. The injector and chromatograph oven maintained a temperature of 150 and $80^{\circ} \mathrm{C}$ throughout the evaluations. Nitrogen was used as a carrier gas throughout the assay. Calibration gas standards (INFRA ${ }^{\circledR}$ ) at a concentration of 460 and $100 \mathrm{mg} \mathrm{L}^{-1}$, respectively, were used for the quantification of $\mathrm{CO}_{2}$ and ethylene.

2.2. Weight Loss. The loss of mass was determined using a digital scale (Scout Pro SP2001, OHAUS ${ }^{\circledR}$, New Jersey, USA) to measure the mass of each individual soursop fruit. The loss of accumulated mass was reported by percentage (\%) relative to the initial mass of the fruit and the mass recorded in each evaluation. To obtain the percentage of accumulated weight, the following formula was used: $\mathrm{Mf}-\mathrm{Mi} / \mathrm{Mi} \times 100$, where $\mathrm{Mf}$ is final mass and $\mathrm{Mi}$ is initial mass.

2.3. Firmness. Firmness was quantified for each individual fruit using the equatorial part of the epidermis on two opposite sides. A tensile and compression testing device (SM-100N-168, Ametek and Chatillon ${ }^{\circledR}$, Florida, USA) was used with a cone probe, which had a $6 \mathrm{~mm}$ base diameter and was $5 \mathrm{~mm}$ in length from the base of the cone to the apex.

2.4. Total Soluble Solids (TSS). The total soluble solids (TSS) were determined by directly placing drops of fruit juice extracted with a manual juice press in a Hanna ${ }^{\circledR}$ HI 96801 USA refractometer ( 0 to $85 \%$ Brix) previously calibrated with distilled water, the results of which were expressed in Brix degrees.
2.5. Titratable Acidity. The titratable acidity was determined by the official method AOAC [22], which consists in homogenizing $1 \mathrm{~g}$ of pulp with $10 \mathrm{~mL}$ of distilled water, the macerate was filtered with a blanket, and $5 \mathrm{~mL}$ aliquots of the filtrate were taken. Subsequently the volumetric titration was done with sodium hydroxide $(0.1 \mathrm{~N} \mathrm{NaOH})$ and phenolphthalein as indicator; the results were expressed as a percentage of ascorbic acid.

2.6. Total Phenolic Compounds. The total phenol content was determined using the method proposed by Singleton et al. [23]. For this, $1 \mathrm{~g}$ of pulp was homogenized with distilled water using an Ultraturrax (T8 IKA ${ }^{\circledR}$ Staufen, Germany), after which the homogenized liquid was filtered, from which $0.5 \mathrm{~mL}$ of the filtered liquid was taken using $2.5 \mathrm{~mL}$ of FolinCiocalteu reagent (diluted 1:10 with distilled water) and left to stand for $5 \mathrm{~min}$, to which $2 \mathrm{~mL}$ of sodium carbonate was added $7.5 \%(\mathrm{p} / \mathrm{v})$. The absorbency of the solution at $760 \mathrm{~nm}$ was then measured. The total phenol content was obtained with a calibration curve using gallic acid $\left(10-100 \mathrm{mg} \mathrm{L}^{-1}\right)$ and expressed as mg equivalents of gallic acid (mg EGA/100 g of fresh weight).

2.7. Polyphenol Oxidase (EC. 1.14.18.1; PPO). The polyphenol oxidase activity (EC. 1.14.18.1; PPO) was undertaken by homogenizing $1 \mathrm{~g}$ of pulp with $7 \mathrm{~mL}$ of cold Tris- $\mathrm{HCl} 0.1 \mathrm{M}$ buffer ( $\mathrm{pH}$ 7.1), using a tissue homogenizer. Throughout this procedure, the samples were kept in trays with ice and then centrifuged (Z326K Hermle, Wehingen, Germany) for $20 \mathrm{~min}$ at $18510 \mathrm{~g}$ and $4^{\circ} \mathrm{C}$. The polyphenol oxidase activity assay (EC. 1.14.18.1; PPO) was undertaken as described by Tejacal et al. [24], where $2.8 \mathrm{~mL}$ of catechol dissolved in Tris- $\mathrm{HCl}$ solution and $0.2 \mathrm{~mL}$ of supernatant was placed in a $3 \mathrm{~mL}$ quartz cell, in order to determine the change in absorbance over $5 \mathrm{~min}$. The results were reported as units of enzymatic activity per milligram of protein $\left(\mathrm{U} \mathrm{mg}^{-1}\right.$ of protein), in which a $U$ was defined as a 0.001 change in absorbance. The soluble protein was determined with the Bradford [25] method, using the liquid filtered from the extraction of the PPO enzyme.

2.8. Pectin Methylesterase (EC. 3.1.1.11; PME). The determination of the activity of the enzyme pectin methylesterase (EC. 3.1.1.11; PME) began with the extraction of the same, homogenizing $1 \mathrm{~g}$ of pulp with $13 \mathrm{~mL}$ of a sodium chloride $(\mathrm{NaCl})$ solution with an $8.8 \%(\mathrm{p} / \mathrm{v})$ concentration for $3 \mathrm{~min}$, after which the mixture was centrifuged (Z326K Hermle, Wehingen, Germany) at $18510 \mathrm{~g}$ for $20 \mathrm{~min}$ at $4^{\circ} \mathrm{C}$. The $\mathrm{pH}$ of the supernatant obtained was adjusted to 7.5 with $\mathrm{NaOH}$ $(0.1 \mathrm{~N})$. To determine PME activity, $100 \mu \mathrm{L}$ of the supernatant was taken, to which the following was added: $200 \mu \mathrm{L}$ of $\mathrm{NaCl} 0.15 \mathrm{M}$ solution; $200 \mu \mathrm{L}$ of distilled water; $100 \mu \mathrm{L}$ of bromothymol blue solution at $0.01 \%$; and $1000 \mu \mathrm{L}$ of pectin solution $(0.01 \%)$, adjusted to a $\mathrm{pH}$ of 7.5 with $\mathrm{NaOH}(0.1 \mathrm{~N})$. The absorbance was taken using a wavelength of $620 \mathrm{~nm}$, for 0 and $5 \mathrm{~min}$. The results were reported as units of enzymatic activity per milligram of protein ( $\mathrm{U} \mathrm{mg}^{-1}$ of protein), where one $U$ is equal to the formation of $1 \mu \mathrm{mol}$ of D-Galacturonic acid per minute [26]. The soluble protein was determined 


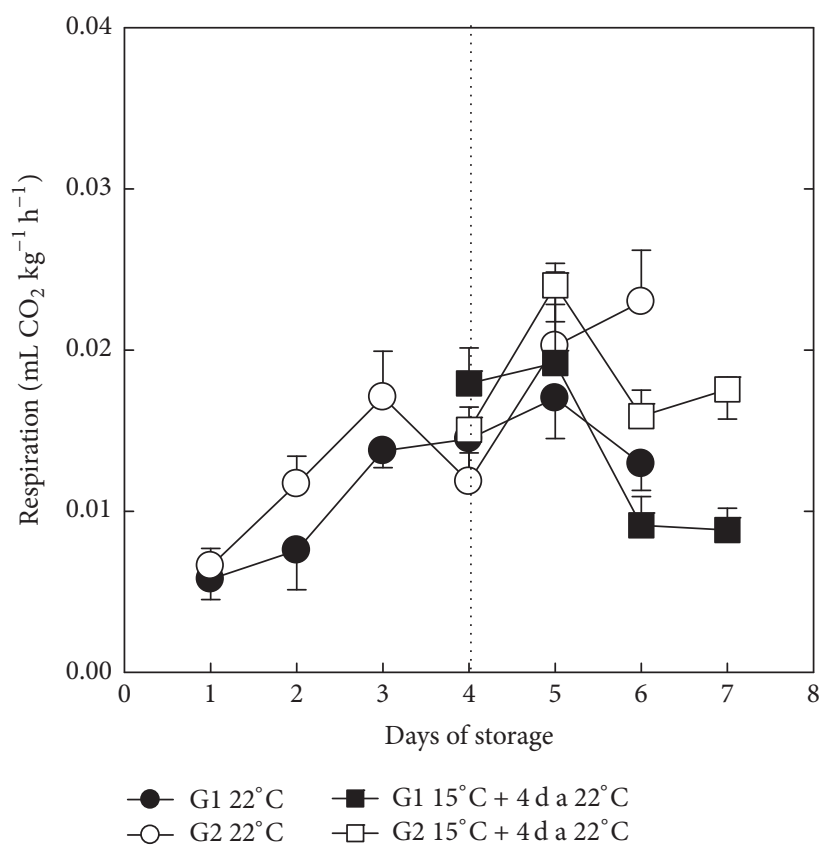

(a)

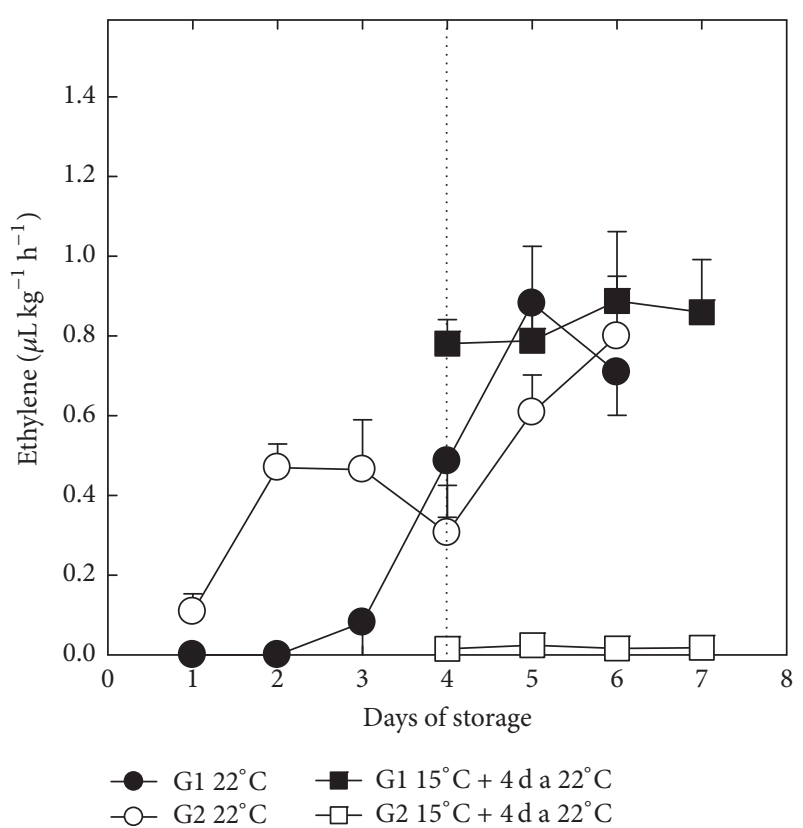

(b)

Figure 1: Respiration (a) and production of ethylene (b) in fruit from two selections of soursop stored at 22 and $15^{\circ} \mathrm{C}$. Each point represents the average of 6 observations \pm standard error. The dotted line indicates removal from refrigeration.

with the Bradford [25] method, using the extract to evaluate PME activity.

The data analysis was performed using ANOVA and Tukey's method comparison $(P \leq 0.05)$ with the $S A S^{\circledR}$ version 9.2 statistical package (Copyright $\odot$ 2009, SAS Institute Inc., Cary, North Carolina, USA), using the general linear model (GLM) procedure as indicated by Castillo [27].

\section{Results and Discussion}

3.1. Respiration and Ethylene. Respiration of the fruits stored at $22^{\circ} \mathrm{C}$ from the G1 and G2 selections increased during the evaluation period, reaching a maximum 5 days after the evaluation began (Figure 1(a)).

Espinosa et al. [11] determined the maximum respiration production on the 4 th day of storing soursop fruits at $25^{\circ} \mathrm{C}$. Worrell et al. [20] indicate that the respiration of the soursop is biphasic; namely, it passes through two periods of identified respiration. The foregoing can be attributed to differences in the physiological ages of the tissues of the different fertilized ovaries. The increase in the initial respiration rate is due to the increase in the mitochondrial respiration caused by the increase in the supply of carboxylated substrates, itself likely induced by the act of harvesting [28]. Both this research and that reported by Espinosa et al. [11] did not clearly detect biphasic respiration, which is probably due to the measurement intervals of $24 \mathrm{~h}$ used in both studies.

The soursop fruits from both selections, G1 and G2, reached the maximum $\mathrm{CO}_{2}$ production two days after the storage period (Figure 1(a)). No differences were detected
$(P \geq 0.05)$ in the respiration rate between the two selections when stored at a low temperature (Figure 1(a)).

Espinosa et al. [11] stored soursop fruits at $16^{\circ} \mathrm{C}$, measuring a lower respiration rate than those stored at $25^{\circ} \mathrm{C}$. In this study, the fruit stored at $15^{\circ} \mathrm{C}$ and then transferred to storage at $22^{\circ} \mathrm{C}$ demonstrated similar respiration values to those maintained at $22^{\circ} \mathrm{C}$ (Figure $1(\mathrm{a})$ ).

3.2. Weight Loss. The soursop fruit from selections G1 and G2 stored at $22^{\circ} \mathrm{C}$ underwent a daily mass loss of 1.41 and $1.34 \%$, respectively (Figure 2(a)). This loss of mass accumulated during ripening was between 6.7 and $7.1 \%$, with no significant differences detected between $(P \geq 0.05)$ the selections (Figure 2(a)).

The fruit stored at $15^{\circ} \mathrm{C}$ for 4 days presented a loss of accumulated mass of between 2.3 and $2.7 \%$ by the end of storage (Figure 2(a)). During the period subsequent to storage, the daily mass loss was significantly greater in the fruits from selection $\mathrm{Gl}\left(1.9 \% \mathrm{~d}^{-1}\right)$ than those from selection G2 $\left(0.8 \% \mathrm{~d}^{-1}\right)$, accumulating, by the end of the evaluation, 5.9 and $4.7 \%$ of mass loss, respectively (Figure 2(a)). Lima and Alves [5] indicate that postharvest losses of soursop fruit mass of between 4.6 and $11.8 \%$ did not cause wilting, although the spines did become flaccid and dark. Lima et al. [29] report daily mass losses in soursop fruits farmed in Brazil of $1.0 \%$ and losses of accumulated mass of $5.1 \%$ after 5 days at $26.3 \pm 0.6$ and $88 \pm 12 \%$ of $\mathrm{RH}$. The results obtained indicate that when stored at ambient temperatures, the selections of soursop present behavior similar to the fruit stored at $15^{\circ} \mathrm{C}$ for 4 days in terms of mass loss. However, after refrigeration, a differential response was observed between the selections 


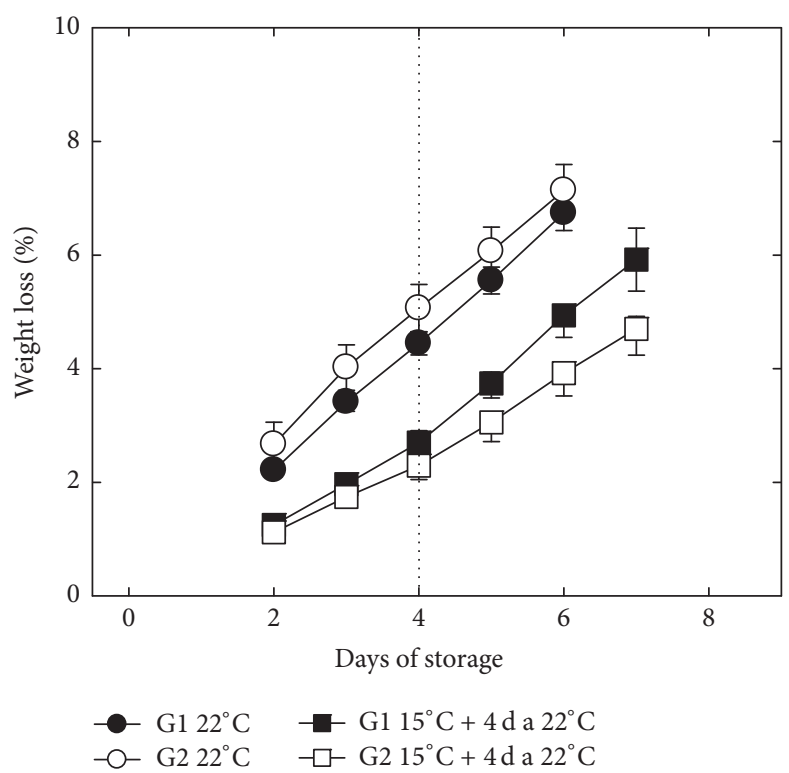

(a)

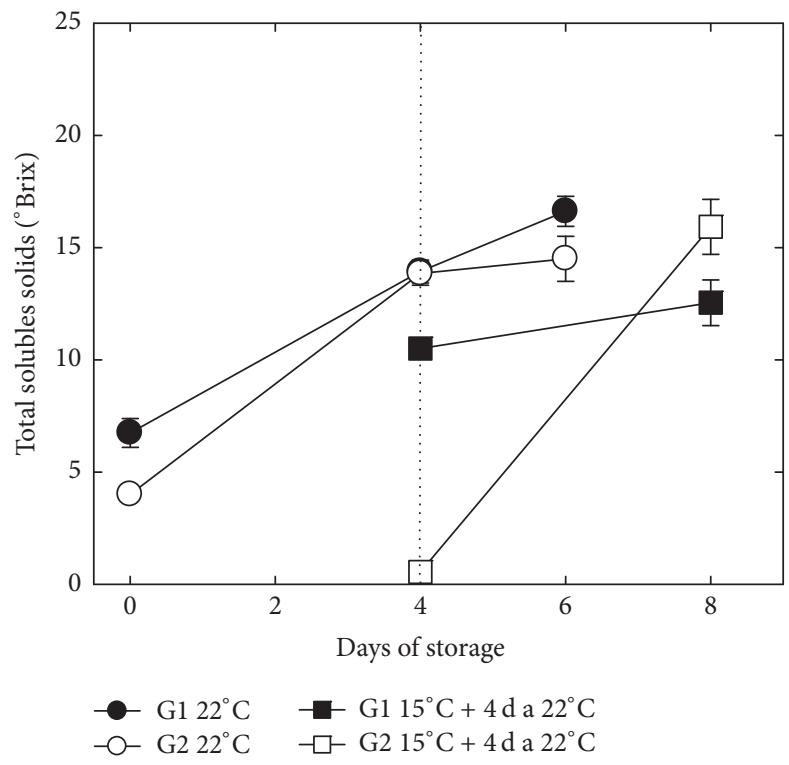

(c)

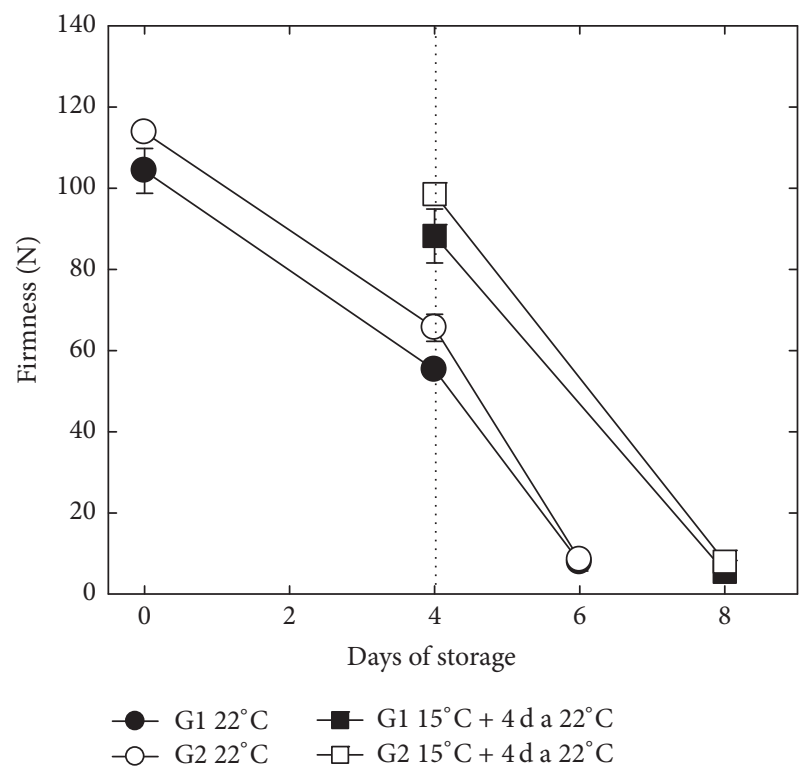

(b)

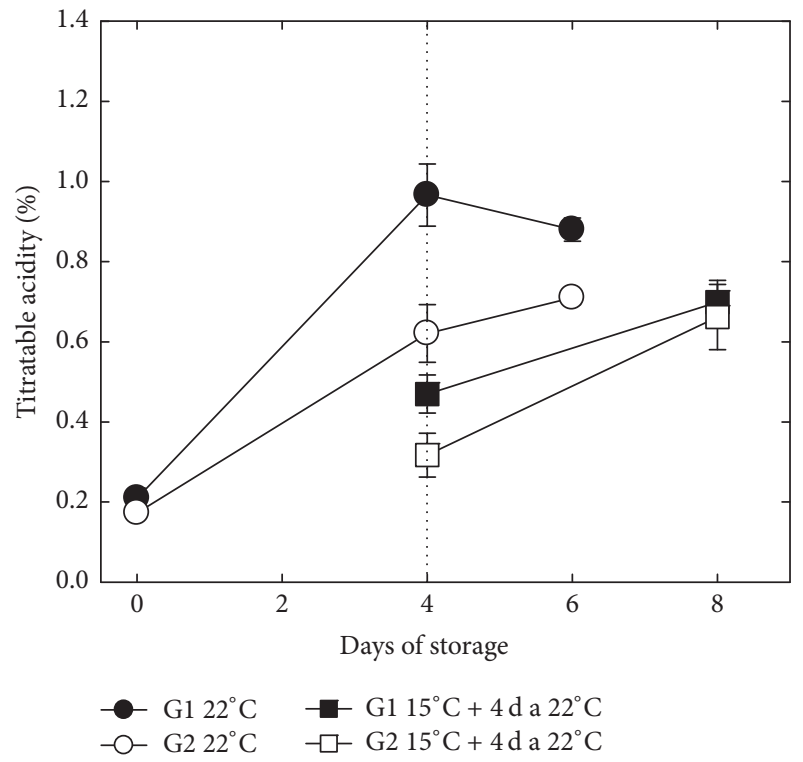

(d)

Figure 2: Mass loss behavior (a), firmness (b), total soluble solids (c), and titratable acidity (d) in two soursop selections stored at $22^{\circ} \mathrm{C}$ and $15^{\circ} \mathrm{C}$. Each point represents the average of 6 observations and its standard error. The dotted line indicates the end of the refrigeration period.

evaluated; in that selection G2 presented a lower level of mass loss compared to selection G1.

3.3. Firmness. The firmness of the fruit from selections $\mathrm{G} 1$ and G2 stored at $22^{\circ} \mathrm{C}$ decreased constantly, presenting, at the beginning of harvest, average values of between 104.2 and $113.7 \mathrm{~N}$, while, 6 days later, on ripening, firmness decreased by $93.51 \%$, between 7.8 and $8.4 \mathrm{~N}$ (Figure 2(b)). MárquezCardozo et al. [30] report that soursop cv. Elita presented values of $80 \mathrm{~N}$ at harvest, with the maximum rate of firmness loss occurring between 2 and 4 days after harvest. On the fifth day of evaluation, the ripened fruit presented between
4.72 and 7.48 N. Espinosa et al. [11], in their research on a soursop cultivar in Nayarit, Mexico, report firmness of $313 \mathrm{~N}$ at the point of harvest and of $5.3 \mathrm{~N}$ after 4 to 5 days at a temperature of $25^{\circ} \mathrm{C}$ and $85-90 \% \mathrm{RH}$. The results obtained in this research indicate that that the loss of firmness is similar in both selections evaluated. This parameter presents high values at ambient temperature of between 22 and $26^{\circ} \mathrm{C}$ and 65 and $90 \% \mathrm{RH}[11,30]$.

On completion of the refrigeration stage, the fruits from both selections demonstrated similar firmness values of between 88.2 and $98.5 \mathrm{~N}$. After 6 days at ambient temperature $\left(22^{\circ} \mathrm{C}\right)$, firmness decreased drastically to between 5.5 and 
$8.0 \mathrm{~N}$, for G1 and G2, respectively (Figure 2(b)). No significant differences $(P \geq 0.05)$ were detected between the selections evaluated for the firmness variable. Espinosa et al. [11] report that the storage of soursop at $16^{\circ} \mathrm{C}$ reduces the rate of firmness loss, where, by the ninth day of storage under this condition, the fruit attained ripeness of $5.1 \mathrm{~N}$. These authors indicate that refrigeration decreases cellular degradation by decreasing enzymatic activity.

3.4. Total Soluble Solids (TSS). The total soluble solids were significantly higher $(P \leq 0.05)$ in the G1 selection stored at $22^{\circ} \mathrm{C}$ in the ripening phase, reaching $16.6^{\circ}$ Brix (Figure $2(\mathrm{c})$ ), as compared to the fruit from selection G2, which, when ripe, presented $14.5^{\circ}$ Brix (Figure 2(c)). Sacramento et al. [31] report three types of soursop in Brazil-purple, smooth, and common-recorded between 12.1 and $13.8^{\circ}$ Brix when ripe. de Lima et al. [32] found $14.4^{\circ}$ Brix in the pulp of another type of soursop in Brazil. de Rodríguez et al. [33] report between 14 and $16^{\circ}$ Brix in Venezuelan soursop, a variation which they attribute to the region in which the species is produced. The results obtained indicate that selection G1 surpassed the total soluble solid values recorded in other regions.

The concentration of soluble solids was low in selection G2 $\left(0.54^{\circ} \mathrm{Brix}\right)$ by the end of storage at $15^{\circ} \mathrm{C}$ compared to selection $\mathrm{Gl}\left(10.5^{\circ} \mathrm{Brix}\right)$. Four days after the completion of the storage period, the total soluble solid content for selection G2 (15.9 $9^{\circ}$ Brix) significantly increased compared to selection G1 (12.5 Brix) (Figure 2(c)). Espinosa et al. [11] report that soursop fruit from Nayarit reaches $18^{\circ}$ Brix after being stored at $16^{\circ} \mathrm{C}$ for 10 days and that the increase in total soluble solids can be attributed to the hydrolysis of starch, sucrose, pectins, and other soluble compounds such as organic acids or amino acids. The results suggest that, in refrigeration, selection G2 attained a higher soluble solid content. Statistically significant differences $(P \leq 0.05)$ were found between both selections.

3.5. Titratable Acidity. The titratable acidity of the two selections of soursop increased during ripening (Figure 2(d)). Selection G1 presented the higher titratable acidity level at $22^{\circ} \mathrm{C}$, with values between 0.88 and $0.96 \%$, while selection G2 only achieved between 0.62 and $0.71 \%$ after 4 to 6 days, respectively (Figure 2(d)). Sacramento et al. [31] report that purple, smooth, and common soursop reported between 0.92 and $1.0 \%$ titratable acidity when ripe. Mosca et al. [34] indicate that, during ripening, the titratable acidity of the soursop fruit increases from 0.067 to $0.67 \%$ in malic acid, due to an increase in the concentration of malic and citric acid.

No differences between $(P \geq 0.05)$ the selections evaluated were observed in the titratable acidity content after storage at $15^{\circ} \mathrm{C}$ for 4 days (Figure 2(d)). Espinosa et al. [11] indicate that titratable acidity is maintained at $0.67 \%$ after 10 days at $16^{\circ} \mathrm{C}$, which they attribute to refrigeration. Titratable acidity increased in this study after the completion of storage at $15^{\circ} \mathrm{C}$, presenting values similar to those reported in the literature (Figure 2(d)).

3.6. Chilling Injury. The groups of fruit G1 and G2 stored at $15^{\circ} \mathrm{C}$ and then transferred to a temperature of $22^{\circ} \mathrm{C}$ did not suffer chilling injury and then ripened normally without presenting any pulp or peel damage, and, furthermore, did not demonstrate aromas characteristic of fermented fruit. The symptoms of chilling injury in the fruit of the soursop are as follows: darkening of the peel; inability to ripen; discoloration of the pulp; the maintenance or increase in pulp firmness; internal decomposition; loss of ripening capacity; and increased senescence [1]. There are reports of fruit stored at $15^{\circ} \mathrm{C}$ suffering chilling injury [15], which does not concur with what is reported in this study. This is likely due to the fact that the fruits were harvested at an advanced stage of ripening; in that if they are harvested before physiological maturity, there is a greater susceptibility to chilling injury [15].

3.7. Total Phenolic Compounds. The fruit exposed to $22 \pm$ $2{ }^{\circ} \mathrm{C}$ from selection $\mathrm{G} 1$ presented a higher concentration of phenols (74.20 mg GAE/100 g.f.w.) compared to the fruit from selection G2 (63.05 mg GAE/100 g.f.w.) at the beginning of the experiment (Figure 3(a)). No significant changes were observed $(P \geq 0.05)$ in the concentration of total phenols during the ripening of selection G2, which was not the case with the fruit from selection G1, in which a drastic decrease to values of $64.09 \mathrm{mg}$ GAE/100 g.f.w. was observed on the sixth day of evaluation (Figure 3(a)). In fruit cultivated in Sri Lanka, Padmini et al. [35] report total phenol content values of $21.96 \mathrm{mg}$ per $100 \mathrm{~g}^{-1}$ of fresh weight. Fresh weight values of $0.32 \mathrm{mg}$ per $100 \mathrm{~g}^{-1}$ have been reported in Brazil, [36], while in Mexico, Moreno-Hernández et al. [37] report values of $2.55 \mathrm{mg}$ per $100 \mathrm{~g}$ dry weight. Da Silva et al. [38] report values of $2886.6 \pm 119.0 \mathrm{mg}$ per $100 \mathrm{~g}$ dry weight for total phenols in the pulp of soursop grown in Brazil. The difference in values in terms of the total phenol content is attributed to the different methods of extraction and the kinds of fresh and dry material used. Recently, Jiménez et al. [7] identified 16 phenolic compounds in soursop pulp, where the principal phenols are derived from cinnamic acid and $p$-coumaric acid, the consumption of which has been determined to be of benefit to human health. Subsequent studies will need to identify what happens with the phenols from selections G1 and G2 and the effect of postharvest technologies on these molecules.

The fruit from the selections G1 and G2 stored at $15^{\circ} \mathrm{C}$ for 4 days and subsequently exposed at $22^{\circ} \mathrm{C}$ presented initial concentrations of 73.76 (G1) and 66.24 GAE/100 g.f.w. (G2), respectively (Figure 3(a)). Subsequently, the concentration of phenols in both selections decreased to 58.49 and 44.94 GAE/100 g.f.w. (Figure 3(a)). An analysis of variance detected significant differences between both selections $(P \leq 0.05)$. Moreno-Hernández et al. [37] reported concentrations of phenolic compounds of $2.61 \mathrm{~g}$ GAE/100 g of dry weight for fruits from Compostela, Nayarit, which were stored at $16^{\circ} \mathrm{C}$. These differences in total phenol concentration could be influenced by geographical origin, cultivar, harvesting, and storage time, as well as the sample extraction methods [39].

3.8. Polyphenol Oxidase (EC. 1.14.18.1; PPO). As the enzymatic activity of PPO increased during the ripening of the 


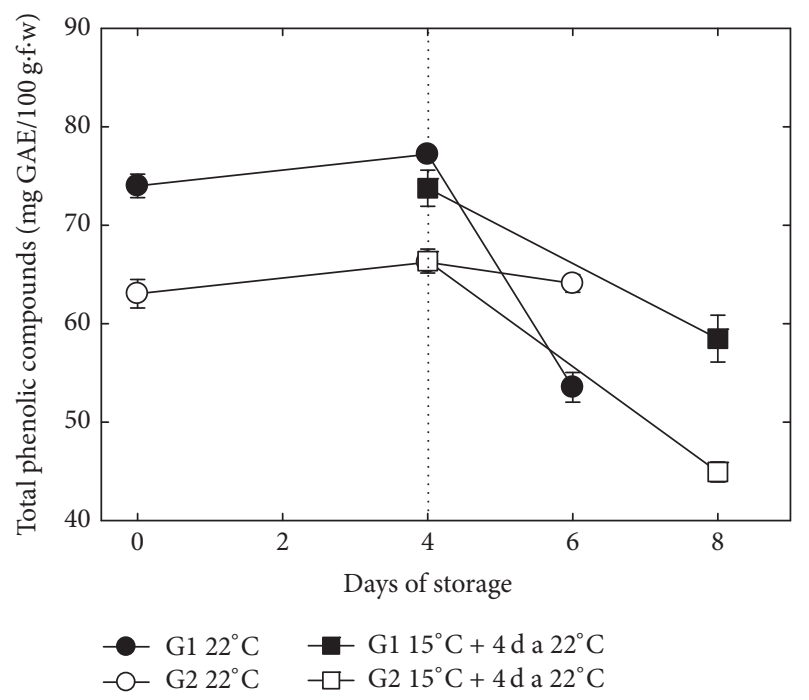

(a)

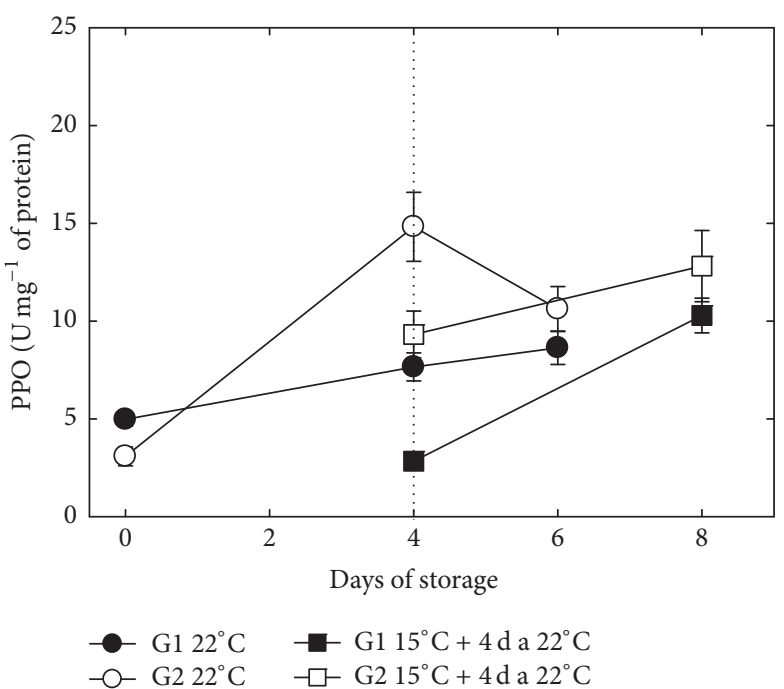

(b)

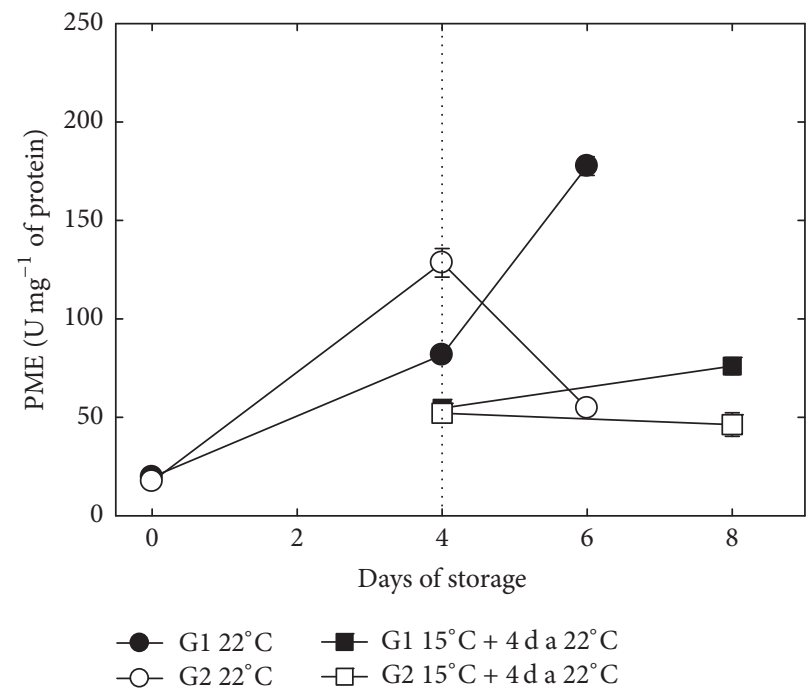

(c)

Figure 3: Total phenol content (a) and enzymatic activity of PPO (b) and PME (c) in fruit from two selections of soursop stored at two temperatures, 22 and $15^{\circ} \mathrm{C}$. Each point represents the average of 6 observations and their standard error. The dotted line indicates the end of refrigeration.

fruit stored at $22^{\circ} \mathrm{C}$, the fruit from selection G1 increased initial activity from 4.97 to $8.64 \mathrm{U}$ on the sixth day (Figure 3(b)), while the fruit from selection G2 initially presented activity of $3.0 \mathrm{U}$, which increased to $10.62 \mathrm{U}$ by the sixth day (Figure 3(b)). Selection G1 presented significantly $(P \leq$ $0.05)$ greater enzymatic activity for PPO than selection G2 (Figure 3(b)). Studies undertaken by de Lima et al. [32] indicate that, during ripening, the enzymatic activity of PPO in soursop fruit increases from the first to the fourth day of evaluation. Lima De Oliviera et al. [40] report that the activity of polyphenol oxidase is low in totally ripe fruit, which is attributed to the low likelihood of darkening, as the ripening process advances. While darkening of the soursop fruit pulp from both selections studied in this investigation was not quantifiable, a low but significant correlation $\left({ }^{*} P \leq 0.05\right)$ was observed between the total phenol content and polyphenol oxidase $\left(r=-0.27^{*}\right)$.

Selections G1 and G2 stored at $15^{\circ} \mathrm{C}$ for 4 days and transferred to $22^{\circ} \mathrm{C}$ registered an increase from 2.83 to $10.29 \mathrm{U}$ (G1) and from 9.32 to $12.81 \mathrm{U}$ (G2) (Figure 3(b)). The analysis of variance determined significant differences $(P \leq 0.05)$ between the selections (Figure 3(b)). There are no reports on the behavior of the PPO enzyme in soursop fruits stored at refrigeration temperatures; selection G2 demonstrated a higher level of activity in this study, an important parameter to consider in selecting materials for fresh consumption or industrialization.

3.9. Pectin Methylesterase (EC. 3.1.1.11; PME). During the ripening of fruit stored at $22^{\circ} \mathrm{C}$, the PME activity of selection 
G1 increased by $88.9 \%$, from 19.6 to $177.6 \mathrm{U}$ (Figure 3(c)). The PME activity in fruit from selection G2 registered an increase from 17.39 to $128.47 \mathrm{U}(86.46 \%)$ by the fourth day, after which activity decreased to $54.61 \mathrm{U}$ (Figure 3(a)). Studies on PME activity in the soursop are rare, with reports indicating that PME activity increases when the fruit attains ripeness compared to fruit that is physiologically mature, due to the degradation of pectic substances [29]. PME catalyzes the hydrolysis of pectin methyl esters, due to the fact that it decreases the degree of esterification, reducing intercellular adhesion and tissue stiffness [41]. PME activity correlates negatively $\left({ }^{* * *} P \leq 0.001\right)$ and significantly $\left(r=-0.65^{* * *}\right)$ with firmness. Thus, with a high level of firmness, PME activity was low, while when PME activity was high, firmness was low. The enzymatic activity of PME in the fruit stored at $15^{\circ} \mathrm{C}$ from selection G1 demonstrated a $28.17 \%$ increase in PME activity, from 54.61 to 76.03 UA (Figure 3(c)), while the activity recorded for selection G2 decreased by $12 \%$, from 52.12 to $46.31 \mathrm{U}$ (Figure 3(c)). Significant differences $(P \leq$ $0.05)$ were found for the two groups, in which selection G2 registered a higher level of activity (Figure 3(c)). Ketsa and Daengkanit [42] propose a correspondence between an increase in the production of ethylene and the metabolic activity of PME, which is then related to the decrease in fruit firmness. Lima et al. [29] report that the greatest increase in PME activity occurs between the third and fourth day, and, by the end of the experiment, the activity was 23 times higher than the initial level. This behavior is not always observed, in that total PME activity can decrease, remain constant, or increase during ripening, depending on the type of fruit and the extraction method.

\section{Conclusions}

The ripening of soursop fruits is characterized by the presence of maximal $\mathrm{CO}_{2}$ and ethylene levels, with increases in the concentration of total soluble solids and titratable acidity, as well as a decrease in weight and firmness. Weight loss was seen to be affected by the storage conditions. The G1 and G2 selections stored at $15^{\circ} \mathrm{C}$ presented a lower level of accumulated weight loss. The G1 selection stored at $22^{\circ} \mathrm{C}$ demonstrated a greater concentration of total soluble solids, while the $\mathrm{G} 2$ selection stored at $15^{\circ} \mathrm{C}$ presented the highest concentration of total soluble solids. The G1 selection stored at 22 and $15^{\circ} \mathrm{C}$ demonstrated the highest level of titratable acidity. The concentrations of phenolic compounds decreased by the end of the ripening process, with the G2 selection exposed to $15^{\circ} \mathrm{C}$ presenting a lower concentration of phenolic compounds. PPO and PME activity are observed to increase during the days subsequent to harvesting, with PPO and PME activity greater in selection G2 during storage at both $22^{\circ} \mathrm{C}$ and $15^{\circ} \mathrm{C}$.

Storage at $15^{\circ} \mathrm{C}$ did not affect the biochemical processes related to ripening, and evaluating the variables, the fruit observed at this temperature did not present chilling injury. The shelf life of the fruit increased to up to 8 days, while conserving the organoleptic properties of ripened fruit.

\section{Competing Interests}

The authors declare that they have no competing interests.

\section{Acknowledgments}

The corresponding author thanks CONACYT for the scholarship awarded (360119) for postgraduate studies and the Sectorial Fund for Research for Education (Fondo Sectorial de Investigación para la Educación), through the project Morphological, Biochemical, and Genetic Characterization of the Soursop (Annona muricata L.) no. 242718.

\section{References}

[1] R. E. Paull, "Soursop," in Tropical and Subtropical Fruits, P. E. Shaw, H. T. Chan, and S. Nagy, Eds., pp. 386-400, AgScience, Auburndale, Fla, USA, 1998.

[2] J. F. Morton, Fruits of Warm Climate, Echo Points \& Media Books, Guilford, Vt, USA, 2013.

[3] R. E. Paull and O. Duarte, Tropical Fruits, vol. 2, CABI Publishing, Oxfordshire, UK, 2011.

[4] SIAP (Servicio de Información Agrícola y Pesquera), Cierre de la Producción Agrícola. Consultado el 2 de Febrero de 2014, 2014, http://www.siap.gob.mx/cierre-de-la-produccion-agricola-porcultivo/.

[5] M. A. C. Lima and R. E. Alves, "Soursop (Annona muricata L.)," in Postharvest Biology and Technology of Tropical and Subtropical Fruits. Volume 4: Mangosteen to White Sapote, E. M. Yahia, Ed., pp. 363-391, Woodhead Publishing, Cambridge UK, 2011.

[6] S. Pareek, E. M. Yahia, O. P. Pareek, and R. A. Kaushik, "Postharvest physiology and technology of Annona fruits," Food Research International, vol. 44, no. 7, pp. 1741-1751, 2011.

[7] V. M. Jiménez, M. Gruschwitz, R. M. Schweiggert, R. Carle, and P. Ssquivel, "Identificación of phenolic compounds in soursop (Annona muricata) pulp by high-performance liquid chromatography with diode array and electrospray ionization mass spectrometric detection," Food Research International, vol. 65, pp. 42-46, 2014.

[8] N. Badrie and A. G. Schauss, "Soursop (Annona muricata L): composition, nutritional value, medicinal uses, and toxicology," in Bioactive Foods in Promoting Health: Fruits and Vegetables, R. Watson and V. Preedy, Eds., pp. 621-643, Academic Press, 2010.

[9] D. Caparros-Lefebvre, "Atypical Parkinsonism in New Caledonia: comparison with Guadeloupe and association with Annonaceae consumption," Movement Disorders, vol. 19, no. 5, p. 604, 2004.

[10] M. A. C. de Lima, R. E. Alves, H. A. C. Filgueiras, and J. EnéasFilho, "Comportamento respiratório e qualidade pós-colheita de graviola (Annona muricata L.) 'Morada' sob temperatura ambiente," Revista Brasileira de Fruticultura, vol. 25, no. 1, pp. 49-52, 2003.

[11] I. Espinosa, R. I. Ortiz, B. Tovar, M. Mata, and E. Montalvo, "Physiological and physicochemical behavior of soursop fruits refrigerated with 1-methylcyclopropene," Journal of Food Quality, vol. 36, no. 1, pp. 10-20, 2013.

[12] E. M. González, A. E. Fernández, H. R. Paez, M. M. Oca, and B. T. Gómez, "Uso combinado de 1-Meticiclopropeno y emulsiones de cera en la conservación de guanábana (Annona 
muricata)," Revista Brasileira de Fruticultura, vol. 36, no. 1, pp. 296-304, 2014.

[13] B. Tovar-Gómez, M. Mata-Montes de Oca, H. S. GarcíaGalindo, and E. Montalvo-González, "Efecto de emulsiones de cera y 1-metilciclopropeno en la conservación poscosecha de guanábana," Chapingo Serie Horticultura, vol. 17, pp. 53-61, 2011.

[14] D. Valero and M. Serrano, Postharvest Biology and Technology for Preserving Fruit Quality, CRC Press, Boca Raton, Fla, USA, 2010.

[15] D. Castillo-Ánimas, G. Varela-Hernández, B. R. Pérez-Salvador, and C. Pelayo-Zaldívar, "Daños por frío en guanábana. Índice de corte y tratamientos postcosecha," Revista Chapingo Serie Horticultura, vol. 11, pp. 51-57, 2005.

[16] J. O. Jiménez-Zurita, R. Balois-Morales, I. Alia-Tejacal, P. Juárez-López, M. T. Sumaya-Martínez, and J. E. Bello-Lara, "Caracterización de frutos de guanábana (Annona muricata L.) en Tepic, Nayarit, México," Revista Mexicana de Ciencias Agrícolas, vol. 7, no. 6, pp. 1261-1270, 2016.

[17] M. Maghoumi, P. A. Gómez, Y. Mostofi, Z. Zamani, F. ArtésHernández, and F. Artés, "Combined effect of heat treatment, UV-C and superatmospheric oxygen packing on phenolics and browning related enzymes of fresh-cut pomegranate arils," LWT_Food Science and Technology, vol. 54, no. 2, pp. 389-396, 2013.

[18] X. Zhang and X. Shao, "Characterisation of polyphenol oxidase and peroxidase and the role in browning of loquat fruit," Czech Journal of Food Sciences, vol. 33, no. 2, pp. 109-117, 2015.

[19] P. Kohli, M. Kalia, and R. Gupta, "Pectin methylesterases: a review," Journal of Bioprocessing \& Biotechniques, vol. 5, article 227, 2015.

[20] D. B. Worrell, C. M. S. Carrington, and D. J. Huber, "Growth, maturation and ripening of soursop (Annona muricata L.) fruit," Scientia Horticulturae, vol. 57, no. 1-2, pp. 7-15, 1994.

[21] M. E. Salveit, "Respiratory metabolism," in Postharvest Ripening Physiology of Crops, S. Pareek, Ed., pp. 139-156, CRC Press. Taylor \& Francis, Boca Raton, Fla, USA, 2016.

[22] AOAC, Official Methods of Analysis, Association of Official Analytical Chemists, Arlington, Va, USA, 18th edition, 2005.

[23] V. L. Singleton, R. Orthofer, and R. M. Lamuela-Raventós, "Analysis of total phenols and other oxidation substrates and antioxidants by means of folin-ciocalteu reagent," Methods in Enzymology, vol. 299, pp. 152-178, 1999.

[24] I. A. Tejacal, M. T. Colinas Leó, M. T. Martínez Damián, and R. M. Soto Hernández, "Daños por frío en zapote mamey (Pouteria sapota (Jacq.) H. E. Moore and Stearn). II. Cambios en fenoles totales y actividad enzimática," Revista Fitotecnia Mexicana, vol. 28, no. 1, pp. 25-32, 2005.

[25] M. M. Bradford, "A rapid and sensitive method for the quantitation of microgram quantities of protein utilizing the principle of protein-dye binding," Analytical Biochemistry, vol. 72, no. 1-2, pp. 248-254, 1976.

[26] A. E. Hagerman and P. J. Austin, "Continuous spectrophotometric assay for plant pectin methyl esterase," Journal of Agricultural and Food Chemistry, vol. 34, no. 3, pp. 440-444, 1986.

[27] L. E. M. Castillo, Introducción al SAS ${ }^{\circledR}$ para Windows, Universidad Autónoma Chapingo, Chapingo, México, 2011.

[28] M. A. C. de Lima, R. E. Alves, and H. A. C. Filgueiras, "Respiratory behavior and softening of soursop fruit (Annona muricata L.) after postharvest treatments with wax and 1methylcyclopropene," Ciencia e Agrotecnologia, vol. 34, no. 1, pp. 155-162, 2010.
[29] M. A. Lima, R. E. Alves, and H. A. Filgueiras, "Mudanças relacionadas ao amaciamento da graviola durante a maturação pós-colheita," Pesquisa Agropecuária Brasileira, vol. 41, no. 12, 2006.

[30] C. J. Márquez-Cardozo, V. Villacorta-Lozano, D. P. YepesBetancur, H. J. Ciro-Velazquez, and J. R. Cartagena-Valenzuela, "Physiological and physico-chemical characterization of the Soursop fruit," Revista Facultad Nacional de Agronomía, Medellín, vol. 65, no. 1, pp. 6477-6486, 2012.

[31] C. K. Sacramento, J. C. Faria, F. L. Cruz, W. d. Barretto, J. W. Gaspar, and J. B. Leite, "Caracterização física e química de frutos de três tipos de gravioleira (Annona muricata L.)," Revista Brasileira de Fruticultura, vol. 25, no. 2, pp. 329-331, 2003.

[32] M. A. C. de Lima, R. E. Alves, and H. A. C. Filgueiras, "Avaliacao da qualidade e da susceptibilidade ao escurecimiento oxidativo de graviola (Annona muricata L.) durante maturacao póscolheita," Proceedings of the Interamerican Society for Tropical Horticulture, vol. 46, pp. 23-26, 2002.

[33] G. O. de Rodríguez, J. Coronado, R. Nava, B. Sulbarán, D. Araujo, and L. Cabrera, "Caracterización físicoquímica de la pulpa de la guanábana (Annona muricata) cultivada en el occidente de Venezuela," Boletín del Centro de Investigaciones Biológicas, vol. 41, no. 2, pp. 151-160, 2007.

[34] J. L. Mosca, R. E. Alves, and H. A. C. Filgueiras, "Harvest and posthar vest handling of sugar-apple and soursop: current research status in brazil and review of recommended techniques," Acta Horticulturae, vol. 485, pp. 273-280, 1999.

[35] S. M. P. C. Padmini, R. Samarasekera, and D. K. N. G. Pushpakumara, "Antioxidant capacity and total phenol content of Sri Lankan Annona muricata L.," Tropical Agricultural Research, vol. 25, no. 2, pp. 252-260, 2014.

[36] C. N. dos Reis, N. B. Ribeiro, L. G. de Lima et al., "Atividade antioxidante e o teor de taninos e fenóis totais dos frutos de Annona muricata L.," VÉRTICES, vol. 15, no. 3, pp. 93-110, 2014.

[37] C. L. Moreno-Hernández, S. G. Sáyago-Ayerdi, H. S. GarcíaGalindo, M. Mata-Montes De Oca, and E. Montalvo-González, "Effect of the application of 1-methylcyclopropene and wax emulsions on proximate analysis and some antioxidants of soursop (Annona muricata L.)," The Scientific World Journal, vol. 2014, Article ID 896853, 7 pages, 2014.

[38] L. M. R. Da Silva, E. A. T. De Figueiredo, N. M. P. S. Ricardo et al., "Quantification of bioactive compounds in pulps and byproducts of tropical fruits from Brazil," Food Chemistry, vol. 143, pp. 398-404, 2014.

[39] N. Babbar, H. S. Oberoi, D. S. Uppal, and R. T. Patil, “Total phenolic content and antioxidant capacity of extracts obtained from six important fruit residues," Food Research International, vol. 44, no. 1, pp. 391-396, 2011.

[40] S. Lima De Oliviera, N. B. Guerra, M. I. Sucupira Maciel, and A. V. Souza Livera, "Polyphenoloxidase activity, polyphenols concentration and browning intensity during soursop (Annona muricata, L.) maturation," Journal of Food Science, vol. 59, no. 5, pp. 1050-1052, 1994.

[41] T. D. C. R. Pires and F. Finardi-Filho, "Extraction and assay of pectic enzymes from Peruvian carrot (Arracacia xanthorriza Bancroft.)," Food Chemistry, vol. 89, no. 1, pp. 85-92, 2005.

[42] S. Ketsa and T. Daengkanit, "Firmness and activities of polygalacturonase, pectinesterase, $\beta$-galactosidase and cellulase in ripening durian harvested at different stages of maturity," Scientia Horticulturae, vol. 80, no. 3-4, pp. 181-188, 1999. 

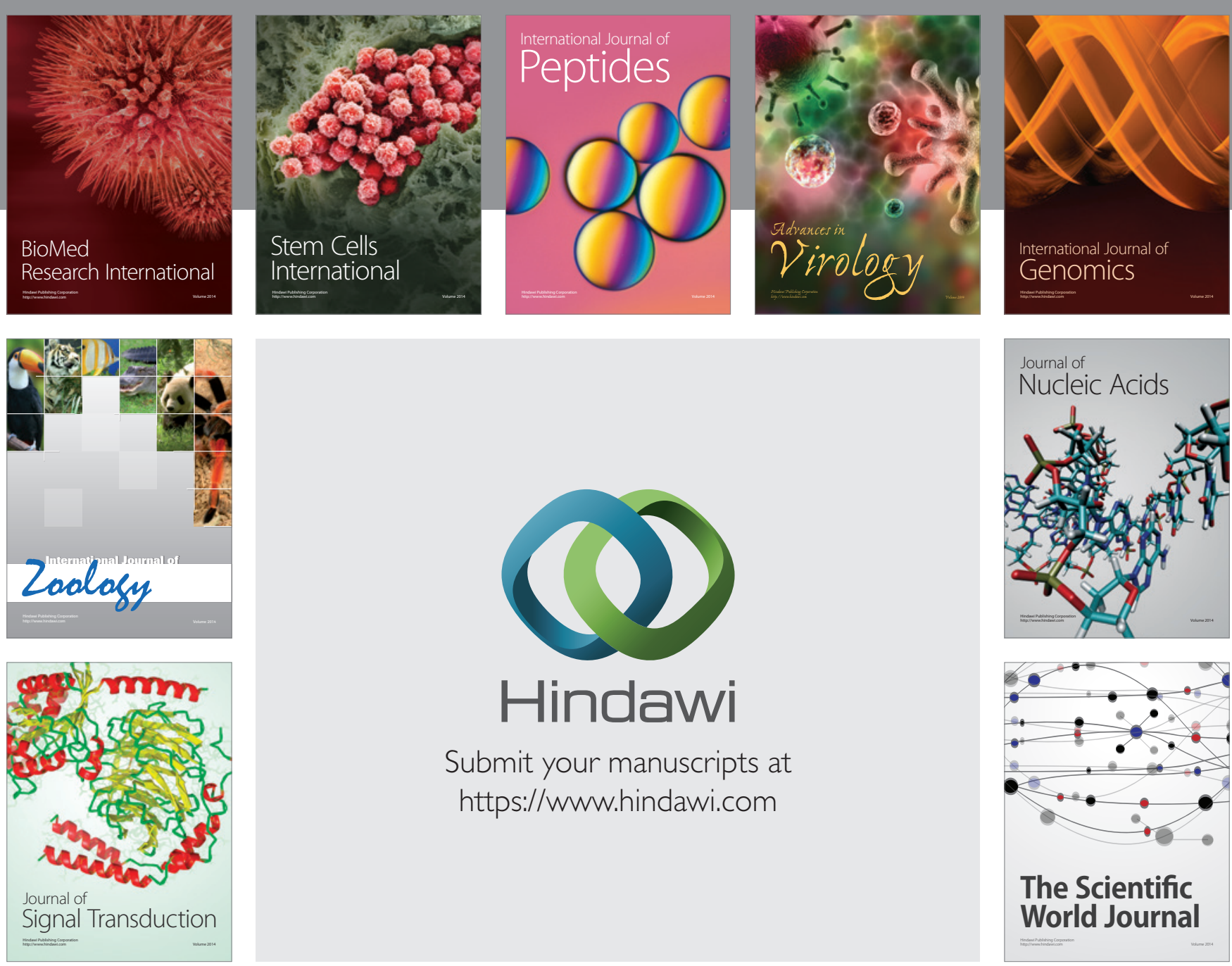

Submit your manuscripts at

https://www.hindawi.com
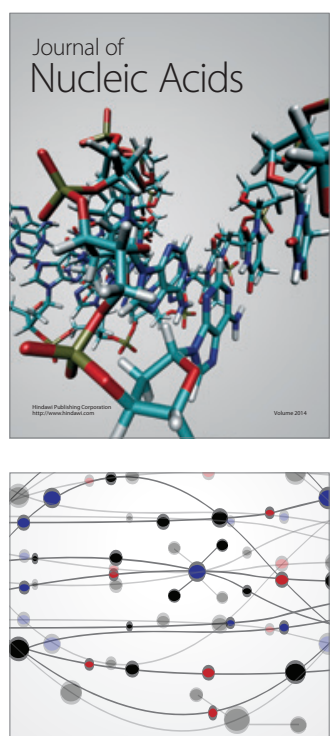

The Scientific World Journal
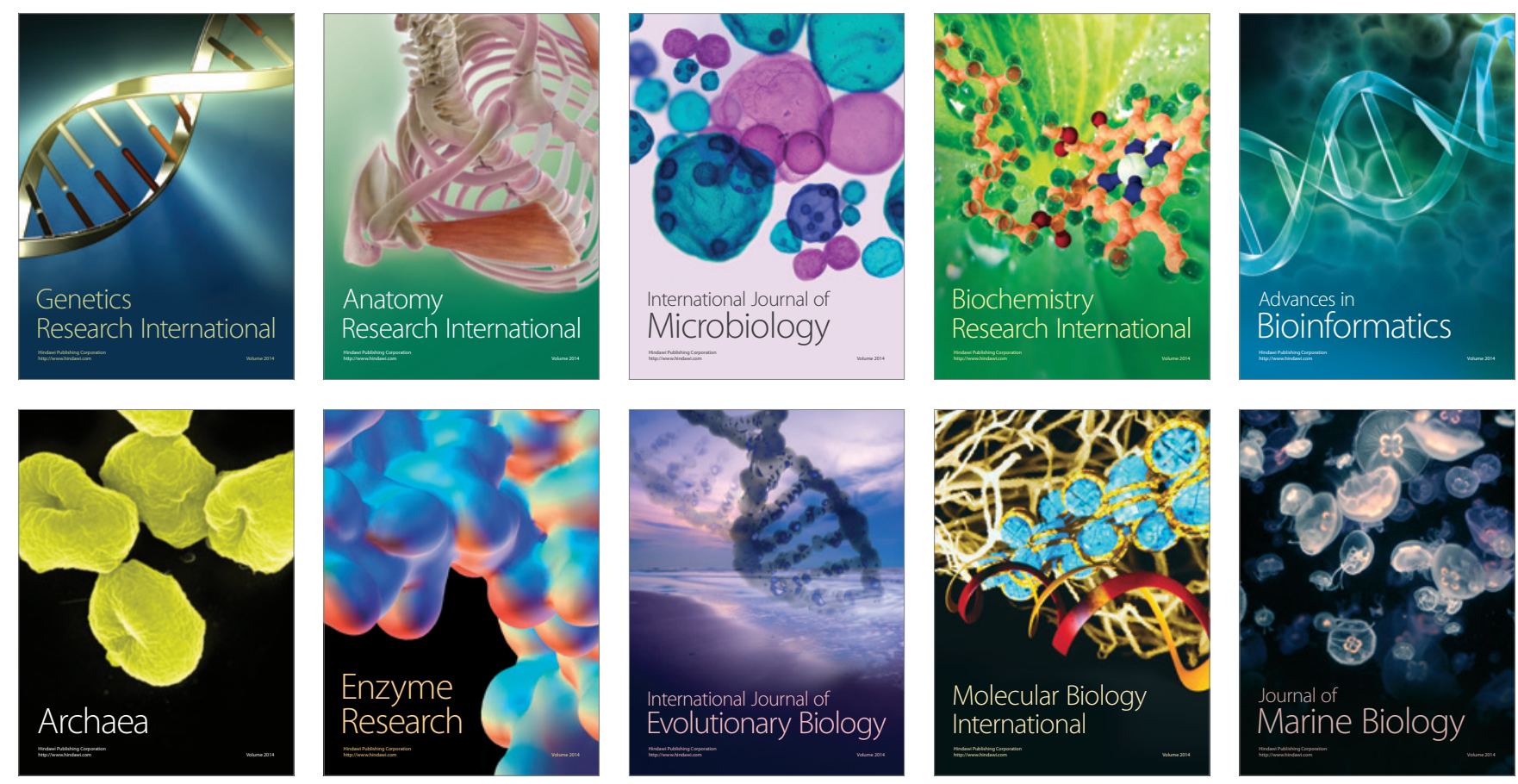